
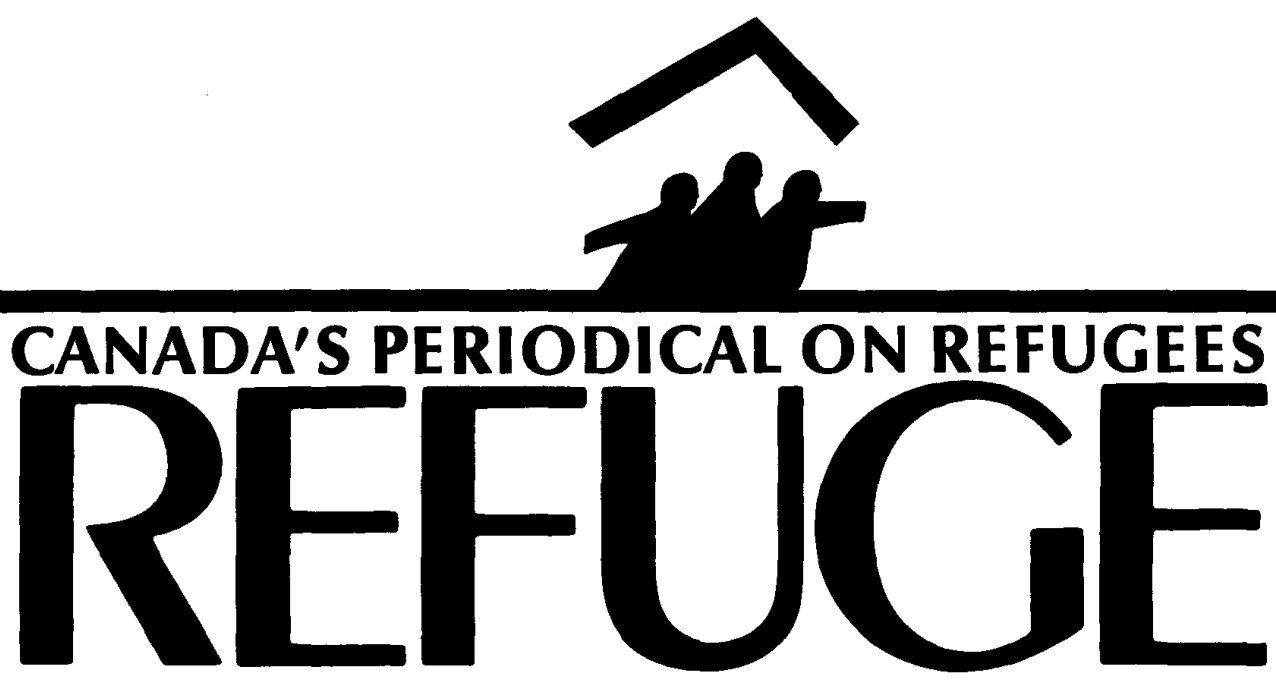

Vol. 2, No. 4

April, 1983

\title{
Defining Refugees
}

\section{by Howard Adelman}

The nomenclature applied to refugees is very confusing. Lists of refugees include Canadian citizens who have been established for 35 years with a proper legal status in their adopted country. But in world refugee surveys they are still counted as refugees. It is poor taxonomy that does not provide a criterion for terminating refugee status.

Refugees are uprooted people whose status as refugees ends when they become re-rooted; that is, when the state in which they live guarantees their legal rights, and when they regard the nationality of that state as their own even though they may have another nationality. For example, Estonians who are refugees from the Russian takeover of their homeland who have become Canadian citizens and nationals do not thereby surrender their Estonian nationality, but they do surrender any status as refugees.

In addition to time boundaries for the beginning and termination of refugee status, there must also be spatial differentiations among the various types of refugees. This is another type of confusion. The difference between Convention refugees and non-Convention refugees, between refugees within a country and refugees outside, are muddled because they are all simply called refugees.

If Muslims flee the state of Assam to
Bengal within India they are referred to as refugees. If a million Ghanians are expelled from Nigeria and return to their home country, they are referred to as refugees. In ordinary language, anyone uprooted because of civil disorder or, sometimes, even natural disaster is referred to as a refugee. But in international law none of these cases qualify the uprooted people for refugee status. The Muslims were given citizenship by India and India sent in the army to provide protection. The returnees to Ghana have their own country to protect them from persecution and to provide material support.

'The main feature of refugee status is that refugees do not enjoy the protection of any government, either because they are, as stateless persons, unable or, having a nationality, unwilling for political reasons to avail themselves of the protection of their country of origin." 1 The modern concept of refugee emerges in an international context in which the world is divided up into nation-states such that everyone is deemed to belong to one nationality or another (though not necessarily only to one), and members of that nationality enjoy the protection of a specific political state.

The narrowest legal definition of refugee is contained in the United Nations Convention Relating to the Status of Refugees (July 28, 1951) and the subsequent Protocol (January 31, 1967). Such refugees must have a nationality and lack the protection of their country of habitual residence (there is no necessary requirement that that country be the individual's country of nationality), but they must be unwilling or unable to avail themselves of the protection of that state by returning to it. The definiton is rather

(Continued on p. 3)
ALSO FEATURED IN THIS ISSUE $\ldots \ldots \ldots \ldots \ldots \ldots \ldots$

QUEBEC'S UNACCOMPANIED MINORS PROGRAMS

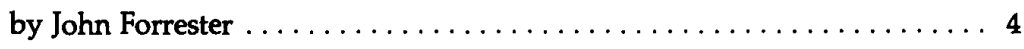

THE INDOCHINESE REFUGEES IN SWEDEN $\ldots \ldots \ldots \ldots \ldots \ldots \ldots$ 


\section{REFUGE}

c/o Refugee Documentation Project,

York University, 4700 Keele Street

Downsview, Ontario M3/2R6

Editor:

Howard Adelman

Managing Editor:

Caroline Stephens

Editorial Board:

Douglas Cohen, Montreal

Claudio Duran, Toronto

Arie van Eek, Burlington

Donald Ferguson, Toronto

James Hathaway, Moncton

Michael Pitman, Toronto

Linda Weigl, Regina

Typesetting and Layout:

Publications Department,

York University

Refuge is dedicated to encouraging assistance to refugees, by providing a forum for sharing information and opinion on Canadian and international issues pertaining to refugees. It is published five times a year, in October, December February, April and June. It is a non-prof independent periodical supported by grants from the Canadian Foundation for Refugees, Operation Lifeline, and the Canada Employment and Immigration Commission; by private donations; and by subscription payments of $\$ 10$ a year. It is a forum for discussion, and the $v$ a year. It is a forum for discussion, and the views expressed do not necessarily reflect those of its funders, staff or Editorial Board.

All material in Refure may be reproduced without permission unless copyrighted or otherwise indicated. Credit should be given to the author or source if named.

\section{Logo design}

Dreadnaught Cooperative Inc., Toronto

Second Class Mail Registration No. 5512 ISSNO229-5113
The Canadian Jesuit Missions have announced the donation of Rs. 10,000 for relief work among Bengali refugees in Assam, India.

***

New special measures will allow Iranian visitors and Minister's Permit Holders in Canada to apply for permanent residence without leaving the country.

About half of the 2,000 Iranians expected to benefit from these measures are students whose funding has been cancelled by the Iranian government. "Many of these students have had their passport renewals denied, and fear reprisals or even death if they return to their homeland," Canada's Employment and Immigration minister said.

Iranian visitors, students and Minister's Permit Holders, will be allowed to apply for landing if they have relatives here who will assist them or if they have been here twelve months and can demonstrate their ability to settle in Canada successfully.

Landing would be granted by Order in Council from within Canada. As permanent residents, these Iranians could apply to sponsor their dependants in Iran, and thus meet the goal of reunifying families.

$$
\text { *** }
$$

\section{Resettlement:}

\section{Indochinese in Transition}

A symposium on aspects of refugee resettlement will be held at the University of British Columbia, July $15-18$, 1983. The symposium is being cosponsored by the Refugee Resettlement
Project (UBC), the World Federation for Mental Health and the Canadian Mental Health Association. For further information please contact Morton Beiser, M.D. Room 2C7, 2255 Wesbrook Mall, University of British Columbia, Vancouver, B.C., V6T 2A1

$$
\text { *** }
$$

Employment and Immigration Minister Lloyd Axworthy announced on February 2, 1983 that persons receiving Unemployment Insurance Benefits will be allowed to take full-time language training if the training is required to obtain employment. The new policy applies equally to all unemployed Canadians who need language training to find work. Benefits will be provided during training and for up to six weeks following the courses while employment is sought.

It is expected that about 15,000 Canadians could qualify under the new policy and that about 5,000 persons a year will take advantage of the change, which will cost about $\$ 2$ million annually.

Language training under the National Training Act is provided to immigrants, refugees and Native persons who are not fluent in either official language. Canadians moving from one province to another are also eligible when lack of fluency in one of the official languages prevents them from finding employment. Prior to this announcement, however, Canadians who did not move from one province to another were not entitled to collect unemployment insurance while attending full-time language training classes.

\section{Letters}

\section{To the Editor:}

I was pleased that The Honourable Charles Lapointe, Minister of State (External Relations) announced that Canada believes that it is important that the international community provide itself with the legal instruments necessary for the effective suppression of the practice of torture in the world. ("Canada Makes Unilateral Declaration Against Torture" Refuge, Volume 2, No. 3. February, 1983) The Minister further announced that Canada has made a unilateral declaration against torture in the United Nations which constitutes a moral com- mitment entailing no change in present Canadian law or practice.

The United Nations has also created the Voluntary Fund for Victims of Torture. A General Assembly resolution was passed urging members of the United Nations to contribute generously to the Fund. Canada has voted in favour of this resolution but has not yet contributed any money to the Fund. Denmark, Norway, The Netherlands, Sweden, Finland and Cyprus have contributed to date.

A moral commitment by the Canadian government against torture is important but a financial commitment is even more important. I would ask the Honourable Minister to use his good offices to encourage the Canadian government to contribute financially to the United $\mathrm{Na}$ tions Voluntary Fund for Victims of Torture. Canada's contribution to the Fund might encourage other members of the United Nations to contribute. This would be consistent with the policy against torture of the Government of Canada and with the resolution in the General Assembly calling for financial contributions which the Canadian government supported. The effective suppression of the practice of torture in the world needs more than a moral commitment from the Canadian government.

Michael S. Schelew Vice-president Canadian Section (Anglophone) Amnesty International 
Defining Refugees (cont'd from p. 1)

narrow because the individuals have to establish that they are potential intentional victims and that the unwillingness to return is motivated by a well-founded fear of persecution for reasons of race, religion, nationality, membership of a particular social group or political opinion. In other words, they not only have a nationality and lack a state to provide protection for them, but have reason to believe that the state currently in charge of their homeland will not provide protection if they return to its jurisdictional boundaries.

The Organization of African Unity on September 10, 1969, adopted a wider definition, but restricted its application to Africa. Refugees did not have to establish that they had reason to believe they were intended victims of persecution. They could be passive victims and simply be outside the country of origin or nationality, "owing to external aggression, occupation, foreign domination or events seriously disturbing public order in either part of the whole of his country of origin or nationality." The OAU Convention, however, makes one very important requirement. The individual must not only be outside his/her national homeland or state of origin, but must be seeking a refuge to establish a peaceful and civil life. Individuals outside their national homeland or state of origin "for the purpose of fomenting subversion from outside" are not refugees.

In sum, legal refugees are those who lack both a national homeland and a legal state to provide protection. There are two types: intentional victims and unintentional victims. Convention refugees who have a well-founded fear of persecution are intentional victims of a lack of protection. Humanitarian refugees are unintended victims of civil disorder or war, but lose that status if they seek to foment conflict rather than seek a new homeland.

But there are other refugees who do not fit into either of these legal conventions. Convention refugees, whether potential intended victims or passive victims of conflict, share two characteristic features: they are outside their homeland and they do not enjoy membership in a state which takes responsibility for their protection. The term refugee, however, may be applied to individuals who are not outside their homeland.

\section{Types of Refugees}

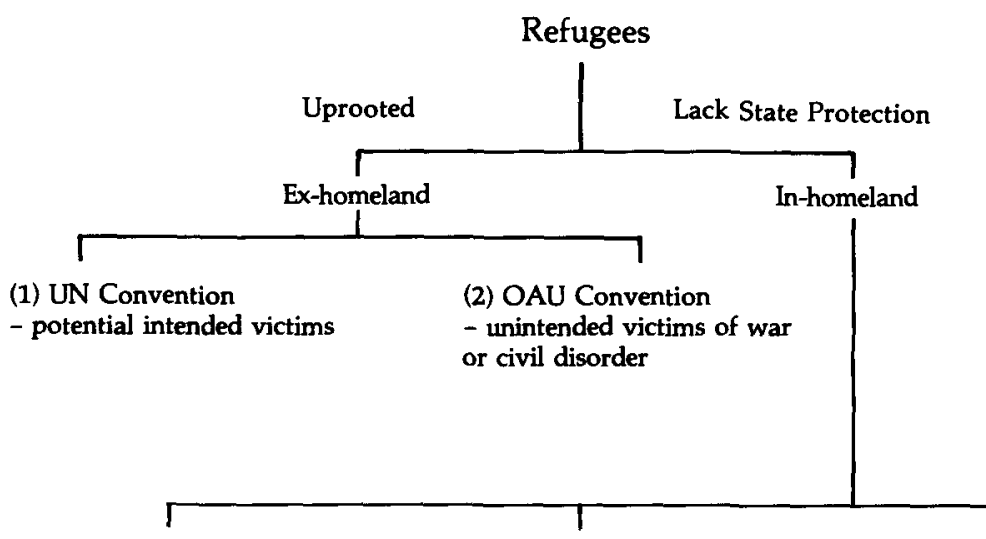

(1) Uprooted persons within boundaries of homeland who remain stateless
(2) Uprooted persons with landed status within a state which is unable to provide protection
(3) Uprooted persons who have legal status in a state which does not govern the territory in which they live
There may be in-homeland refugees. These are individuals who have been uprooted but still live within their national homeland, but that national homeland is governed by a state which is unwilling to guarantee the individual the full protection accorded by the law to its citizens. In the case of the Palestinians uprooted in the 1947-48 war now living in Gaza, though in their homeland, they are stateless persons who cannot count on or are unwilling to count on the full protection of the State currently controlling that part of their homeland.

But the state may be willing but unable to apply such protection. In the case of the Bengalis in Assam, it is the inability of the state to provide protection which makes them refugees.

There is a third type of in-homeland refugee. They were uprooted from part of their homeland, live in another part, but the state governing that part of their homeland is not the state whose citizenship they enjoy. In other words, these individuals are not stateless nor do they live outside their homeland, but the state of which they are members (e.g.Jordan) and the homeland in which they live (the West Bank) do not coincide. The state to which they belong cannot exercise its protective functions over that part of their homeland.

In sum, the in-homeland refugees either are stateless or they are members of a state which does not or cannot govern the homeland in which they live.

The taxonomy illustrated in the above chart reveals that all refugees have two elements in common - they have been uprooted and they lack the full legal protection a state would owe its citizens. They differ in their current location (ex-homeland or in-homeland) and the reasons for lacking protection:

\section{Ex-homeland:}

(1) well-founded fear of persecution by the state which is supposed to provide protection;

\section{(2) civil disorder or war;}

In-homeland:

(3) stateless;

(4) state lacks the adequate ability to provide protection;

(5) state to which they are members does not govern their homeland.

Hopefully, this taxonomy can be tested to see if it clarifies the conception of refugees. Certainly those who have been re-rooted and acquired legal status in another state which accepts responsibility for their protection should not be called refugees.

1Weis, Paul, "The Development of Refugee Law," Transnational Legal Problems of Refugees, 1962 Michigen Yearbook of international Legal Studies, New York: Clark Boardman Company, p 17. Paul Weis is the former Director of the Legal Division of the UNHCR 